\title{
DESIGN AND DEVELOPMENT OF AIR MONITORING AND QUALITY CONTROL DEVICE USING ARDUINO UNO
}

\author{
Widodo*, I Wayan Sudiardana \\ Department of Electrical Engineering \\ University of PGRI Adi Buana Surabaya \\ *Corresponding email address: widodo.adibuana@gmail.com
}

\begin{abstract}
LPG (Liquid Petroleum Gas) has been used in everyday life. But if there is leakage it will cause poisoning and explosion. Underlying this, the authors made research on monitoring and control of air quality. The purpose of this study is to make a device that can detect earlier leakage of LPG. This device can detect excess levels of carbon monoxide in the air. Even more, it can avoid the danger of fire and poisoning. The research method used descriptive analysis method and quantitative analysis method. Measurements and testing with accurate reference measuring instruments. Based on testing and analysis, the device can work well with an average percentage error of $1.92 \%$ for $\mathrm{CO}$ gas measurement and $3.1 \%$ for LPG gas measurement. Increasing gas content in each sensor is proportional of increasing in the sensor output voltage. Some of the factors that cause errors were the differences of sensor sensitivity and environmental conditions where the sample measured.
\end{abstract}

Keywords: CO, LPG, Arduino Uno, MQ-7, MQ-6, monitoring tools, air quality control

\section{INTRODUCTION}

LPG gas has an important role for the needs of human life today. As we know LPG is used for household needs as a substitute for kerosene for cooking. The government is indeed promoting the transition program from kerosene to the use of LPG (Liquid Petroleum Gas) [1]. But on the other hand, Methane/LPG is one of the causes of fires in homes. This is caused by a leak on the regulator. Air containing Methane gas in the air can have a fire potential if ignited by fire. Whereas $\mathrm{CO}$ gas has more negative effects on human life.

Carbon monoxide $(\mathrm{CO})$ is a gas that is odorless, colorless, tasteless and does not irritate. From the explanation above we can take the point of the problem where there is no tool that can detect and prevent early levels of methane and $\mathrm{CO}$ gas in the air.

The purpose of the design is to make a tool that can help the community to know earlier about the existence of LPG gas leak which is certainly very dangerous considering LPG gas has a very sensitive explosive threshold and helps the community to detect excess levels of carbon monoxide gas in the air. With this tool can improve the level of health of the community and avoid the danger of fire and poisoning [2].

The benefits of making the design are able to detect levels and leakage of LPG gas in households and able to read the levels of carbon monoxide in the air and detect excess levels of carbon monoxide gas that triggers poisoning [3].

\section{RESEARCH METHODS}

In making the final assignment in the form of a design tool/prototype, the planning stage is an important stage. At this design stage includes planning components with their specifications, planning design tools/prototypes both planning hardware and software design, and planning the system. The purpose of designing a tool by the author is to produce an appropriate tool and in accordance with the initial planning. To achieve this, studies need to be carried out to overcome the constraints that will be faced when designing both external and internal factors. The circuit uses the Uno Arduino type, the implementation of this design is only limited to the home scale. Accuracy of sensors still requires further calibration and development.

The planning stage of the system from this tool is the making of design diagram blocks in which there is a hardware planning plan. This 
BEST

Journal of Applied Electrical, Science, \& Technology - University of PGRI Adi Buana Surabaya

p-ISSN 2715-2871

e-ISSN 2714-5247

block diagram will guide and simplify the author in designing and analyzing the system of the circuit, including the connection between the circuit components and the overall connection. The following is a block diagram of the design of Arduino Uno-based air quality control and monitoring tools.

The block diagram illustrates that as a whole is a system of acquisition of sensors and is translated by the control center in this case by Arduino Uno. The translation results in the form of digital output for devices in the form of alerts or warnings in the form of buzzers and indicators and displays in the form of LCD.

Arduino Uno is a control center that accepts digital and analog inputs and will respond in digital output and analog output. In the block diagram, Arduino Uno receives data in the form of analog inputs from LPG gas sensors and gas sensors CO. The data is in the form of voltage. The analog data will be converted into digital data by ADC (Analog to Digital) on Arduino Uno. The LPG MQ-6 Gas Sensor detects LPG gas levels and sends data sensing to Arduino Uno continuously. Output data in the form of analog data [4].

The Gas Sensor CO MQ-7 detects CO gas levels and sends data sensing to Arduino Uno continuously [5]. Output data in the form of analog data. 20x4 LCD (Liquid Crystal Display) is a component that functions to display sensor data and air quality status so that it allows the user to know the levels of harmful gases. The buzzer functions as a warning device in the form of sound if detected levels of harmful gases that exceed the limit in the air.

Component LED Indicator that functions as an early warning member in the form of a visual indicator, making it easier for the user to know the condition of a dangerous gas by just looking at the led. Exhaust Fan is a tool to control air quality. If the system detects harmful gas levels that exceed the safe limit, the system will turn on the exhaust fan to remove air from the room. Exhaust fan is optional. Can be connected or not. However, the AC Source will be provided if the design is to be connected to the exhaust fan. Switching relay on the design functions as a switch or switch for the AC Source exhaust fan. Relay switching will receive data in the form of digital output from Arduino Uno if the level of harmful gas exceeds the safe threshold [6].

\section{RESULTS AND DISCUSSION}

At the next stage, a system test is made. Testing is done on several devices or components used.

\section{Calibration Sensors CO MQ-7.}

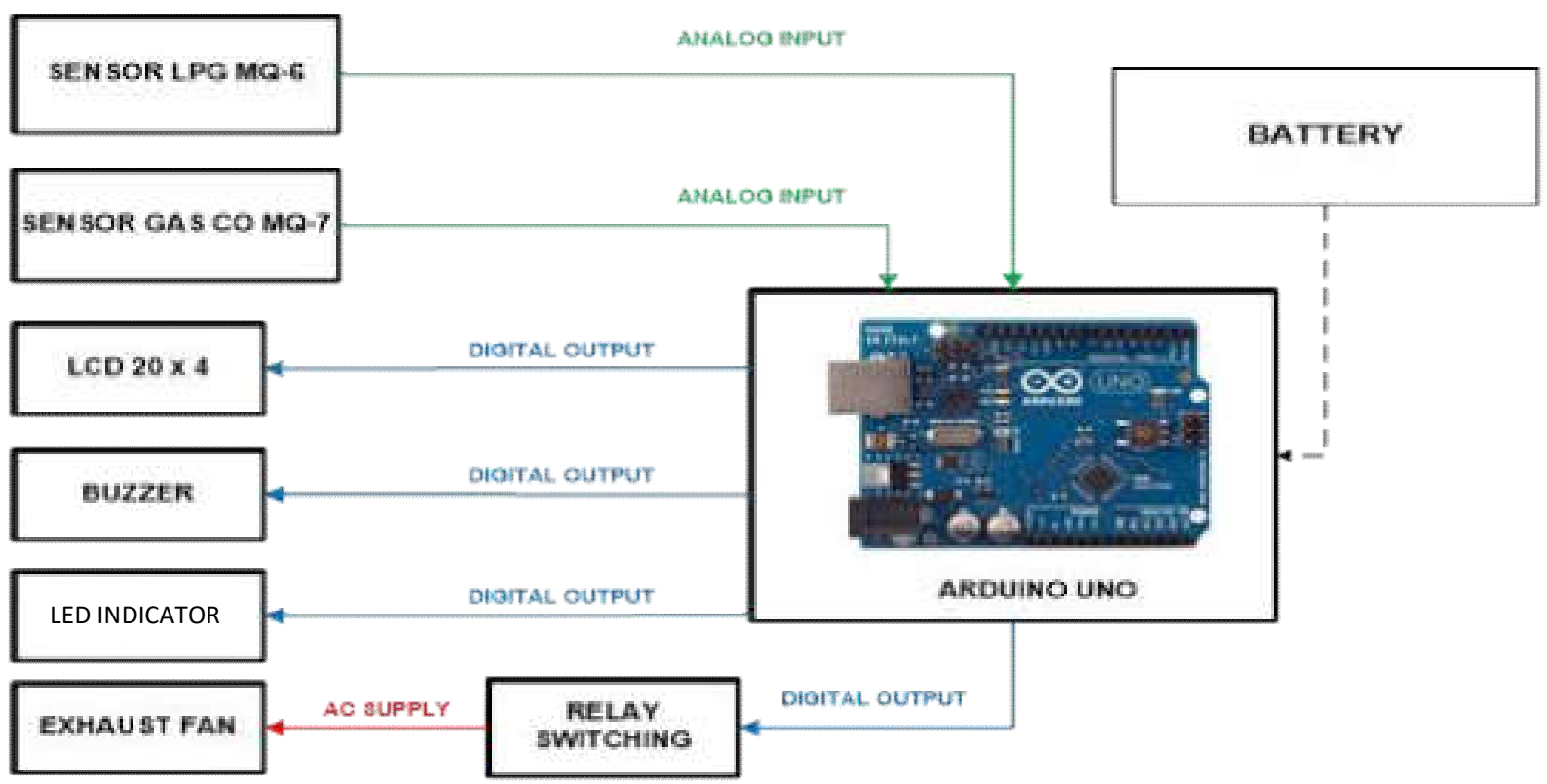

Figure 1. Block diagram of monitoring and quality control device 
BEST

Journal of Applied Electrical, Science, \& Technology - University of PGRI Adi Buana Surabaya

p-ISSN 2715-2871

e-ISSN 2714-5247

The test is done by comparing the concentration value of carbon monoxide (CO) gas in ppm measured by the design of the sensor output voltage. In testing carbon monoxide gas, vehicle exhaust is used as a gas source.

Table 1. Measurement result of $\mathrm{CO}$ sensor

\begin{tabular}{|c|c|c|}
\hline $\begin{array}{c}\text { Measurement } \\
\text { order }\end{array}$ & $\begin{array}{c}\text { Gas concentration } \\
\text { CO (ppm) }\end{array}$ & $\begin{array}{c}\text { Sensor output } \\
\text { (Volt) }\end{array}$ \\
\hline 1 & 0 & 0.06 \\
\hline 2 & 5 & 0.11 \\
\hline 3 & 27 & 0.29 \\
\hline 4 & 80 & 0.57 \\
\hline 5 & 156 & 1.51 \\
\hline
\end{tabular}

From the results of the tests conducted, where every increase in the output voltage, the value of $\mathrm{CO}$ concentration increases.

\section{Calibration Sensors $L P G M Q-6$}

Testing is done by comparing the concentrations of propane and iso butane gas contained in LPG gas in ppm to sensor output voltage.

Table 2. Measurement result of MQ-6 sensor

\begin{tabular}{|c|c|c|c|}
\hline $\begin{array}{c}\text { Measurement } \\
\text { order }\end{array}$ & $\begin{array}{c}\text { Sensor } \\
\text { reading } \\
\text { value }\end{array}$ & $\begin{array}{c}\text { Sensor output } \\
\text { (volt) }\end{array}$ & Condition \\
\hline 1 & $1,25 \%$ & 0,03 & Normal \\
\hline 2 & $3,45 \%$ & 0,07 & Normal \\
\hline 3 & $5,67 \%$ & 0,18 & Normal \\
\hline 4 & $8,86 \%$ & 0,21 & Normal \\
\hline 5 & $10,16 \%$ & 0,27 & Alarm \\
\hline
\end{tabular}

From the graph above shows the concentration of LPG gas is proportional to the value of the voltage coming out of the sensor. Whenever there is an increase in output voltage, the value of LPG concentration increases.

In the following discussion includes discussion of the results of measurement of $\mathrm{CO}$ and LPG gas sensors with reference to measuring instruments. Discussion of Carbon Monoxide Gas Sensors The discussion here includes analysis and testing with $\mathrm{CO}$ gas measuring devices to compare the accuracy of the designed measuring instrument. For data on the results of a comparison test for measuring carbon monoxide $(\mathrm{CO})$ gas.

On the data presented by the graph above, it can be seen that there are not so large differences for some samples of data that are tested together with $\mathrm{CO}$ gas gauges. This difference is likely to occur from error factors such as testing errors, sensor sensitivity differences or elemental levels in testing on gas storage media

The discussion here includes analysis and testing with an LPG gas measuring instrument to compare the accuracy of the designed measuring instrument. For data from the comparison test results for LPG gas measuring devices.

In the data presented by the graph above there can be a considerable difference for some data samples which were tested together with LPG gas measuring devices. This difference is likely to occur from error factors differences in sensor sensitivity or elemental levels in testing on gas storage media. The average error percentage was $1.92 \%$ for $\mathrm{CO}$ gas measurement and $3.1 \%$ for LPG gas measurement.

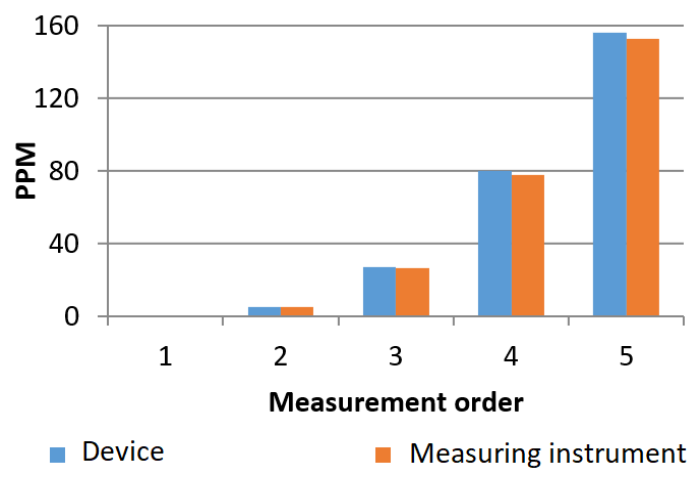

Figure 2. Measurements comparison of $\mathrm{CO}$ between instrument and device

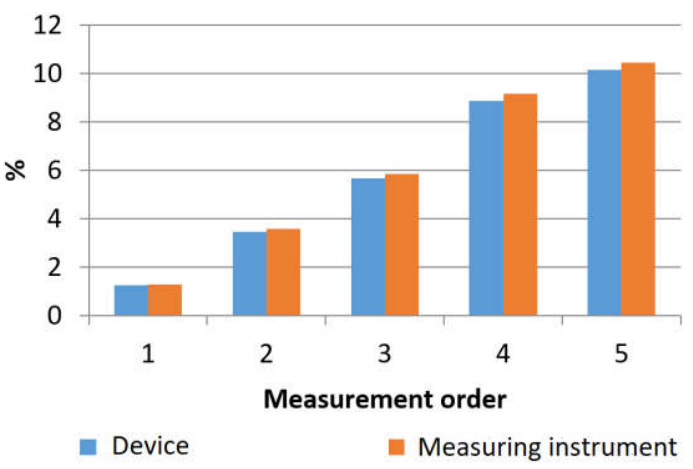

Figure 3. Measurements comparison of LPG between instrument and device 
BEST

Journal of Applied Electrical, Science, \& Technology - University of PGRI Adi Buana Surabaya

p-ISSN 2715-2871

e-ISSN 2714-5247

\section{CONCLUSION}

Based on the design and testing that has been done, it can be concluded that Arduino Uno is a simple minimum system that can be used for various control purposes, Sensor reading - the sensor is directly proportional to the sensor output voltage, based on the tests that have been carried out, the design can run well and can be applied as a safeguard for the household. Based on the results of the design and analysis the average error percentage was $1.92 \%$ for $\mathrm{CO}$ gas measurement and $3.1 \%$ for LPG gas measurement. From the test results, errors are due to the sensitivity of different sensors and air conditions when sampling.

\section{ACKNOWLEDGMENT}

The researcher thanked all the Electrical Engineering Study Program lecturers who had provided input, as well as the Dean of the Faculty of Industrial Engineering and the Head of the Electrical Engineering Laboratory of PGRI Adi Buana Surabaya University who had provided facilities in this research process.

\section{REFERENCE}

[1] "Pertamina Terima Mandat Kelanjutan Program Konversi Minyak Tanah ke LPG - PT Pertamina (Persero).” [Online]. Available:

https://pertamina.com/id/newsroom/energia-news/pertamina-terimamandat-kelanjutan-program-konversiminyak-tanah-ke-lpg-. [Accessed: 06May-2019].

[2] S. Shinde, "Development of Movable Gas Tanker Leakage Detection Using Wireless Sensor Network Based on Embedded System," Int. J. Eng. Res. Appl., vol. 2, 2012.

[3] L. Rosmayati, "Kajian Komposisi Hidrokarbon dan Sifat Fisika-Kimia LPG untuk Rumah Tangga," Lembaran Publ. Miny. dan Gas Bumi, vol. 46, 2012.

[4] H. Alam, "Pendeteksi Kebocoran Gas Elpiji Menggunakan Sensor Gas MQ-5 Berbasis AT89S51," Maj. Ilm. Fak. Teknol. Ind. KEMI, vol. 4, pp. 21-30, 2009.

[5] K. Priyangga, I. Setiawan, and S. Sumardi, "SISTEM KONTROL KADAR GAS CO DAN GAS ELPIJI
DALAM MODEL RUANG SIMULASI," TRANSIENT, vol. 1, no. 4, pp. 333-339, Dec. 2012.

[6] Z. Rakhman and M. I. Ashari, "Perancangan dan Pembuatan Sistem Proteksi Kebocoran Air Pada Pelanggan PDAM Dengan Menggunakan Selenoid Valve dan Water Pressure Switch Berbasis ATMEGA 8535," J. Elektro ELTEK, vol. 3, 2012. 